\title{
Some Considerations About the Chestnut Application in Therapy - The Contribution of Amato Lusitano
}

\author{
Andreia Marlise Carneiro de Carvalho ${ }^{1}$, Isilda Teixeira Rodrigues ${ }^{2}$ \\ ${ }^{1}$ Student of PhD in Earth Sciences and Life of University of Trás-os-Montes and Alto Douro. \\ University of Trás-os-Montes and Alto Douro, Vila Real, Portugal. \\ ${ }^{2}$ Depart. Education and Psychology, Vila Real, Portugal. Research of CIIE - Centre for Research and \\ Educational Intervention, University of Psychology and Educational Sciences, University of Porto, \\ Porto, Portugal.
}

\begin{abstract}
We intend to carry out this work, to contribute for an increased knowledge about the history of science and chestnut as well as identifying the contribution of Amato Lusitano in therapeutic use of Chestnut.

The chestnut has been around for thousands of years helping the man since the Paleolithic. This species was introduced in Europe during the Roman era, due to its potential, representing in our country a large dispersion, a great importance and numerous applications.

The history of science is important in science education, particularly in the teaching-learning process. The content related to this topic enable better learning of scientific concepts and understanding of the dynamic character, collective and socially similar to other human activities, besides being an essential dimension in education of young people.

In methodological terms, we use document analysis and collecteddata from the work book - Centuries of Medicinal Cures, the Portuguese physician, Amato Lusitano (1511 - 1568) was a reference to the Renaissance medicine.
\end{abstract}

Amato Lusitano in his work "Centuries", mentioned the nuts and their derivatives for the treatment of various disorders, such as dysentery and strong and dry cough.

Keywords: Chestnut; AmatoLusitano; Therapeutic applications; Centuries; Dysentery.

\section{INTRODUCTION}

Amato Lusitano (1511-1568), portuguese doctor of the Renaissance, graduated from the University of Salamanca, it was one of the references of European of his Medicine time, its services requested by diverse and distinct personalities, such as, the Pope, the King of Poland, the city-state of Raguza and the Grand Turkish Ottoman Empire [1].

Lusitano perfectly mastered eight languages, including Spanish, Portuguese, Latin, Greek, Arabic and Hebrew, thus allowing and facilitated moved across Europe of his time [2].

In the work Dioscoridis Index (1558), published in Léon, Amato Lusitano presented one chestnut illustration (Figure 1). This image is similar to Leonhart Fuchs published in Naturalis historiae opvs novvm in qvo tracta in 1551, which can be explained by the fact that both both authors may have been aware of each other's work or may have used the same illustrator to draw the pictures plants for their respective works [3][4].

Lusitano wrote several works, among which the best known Centuries of Medicinal Cures, Centuriae Medicinalis (1551-1561). This work is divided into seven volumes constituting a valuable repository of medical and surgical observations, organized in clinical cases standing out the value of direct observation [5]. Each clinical case, that Amato termed Cure, presents the history of the patient and the therapeutic choice to the clinical condition observed by him. Then it refers to clinical outcome often accompanied by the comments and it also describes seven clinical cases, indicating the precise mode of treatment and the results achieved; and generally, adds a brief description of the most relevant characteristics of their patients [2][6]. 


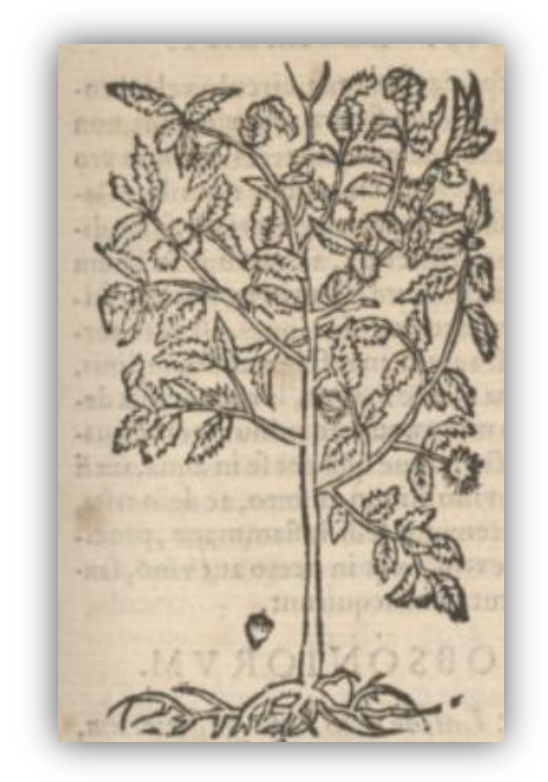

Figure1. Chestnut illustration in the work Index Dioscoridis [3][4].

The portuguese doctor also included in his work comments for each one cure that are appropriate to the evolution of concepts related to the new medicine, from China and the New World, assuming a revolutionary attitude in the XVI century [7].

The same author adds that this work has several editions quickly sold out, showing an transdisciplinary knowledge, while demonstrating the enormous scientific curiosity of Amato Lusitano to observe and explain the world that surrounds.

The Centuries are distinguished not only by the description of a large number of therapeutic discoveries, but also by the variety of topics covered. In all of them, Amato demand to clearly conveythe observations made in each patient and also what he have learned with treatment and progression disease [2].

Since ancient times that the chestnut use, is mentioned by several authors, such as the greek physician Hippocrates (460 b.C - 377 b.C) in the work Hippocratic Oath (IV century b.C in Ancient Greece.) and the greek writer Xenophon (427 b.C. - 355 b.C.) in Anábasis work (377 b.C - 371 b.C in Ancient Greece.). These personalities mention that the nut is a nutritional product that have laxative functions and can usually be consumed cooked or baked [8].

Other research refers that the chestnut cultivation was started in the East, then transmitted to the Greeks, and later was the Romans who spread its widespread cultivation. The chestnut over the centuries, had different names, such as "bread tree", "husband of the wet nurse "," manna" and tree of life "[9]. The denomination of "bread tree", comes from the fact that during the Middle Ages, the chestnut to be grown in different areas of the world, as it was a precious resource for the sustainability of the population and because of the primary importance of chestnuts [10].

Gosselet (1832 - 1916) in his work Cours élémentaire de botanique - description des familles et des espèces utiles, published in Paris in 1898 referring that the chestnuts provided the main food of the peasants, and the cultivation of chestnut trees previous to the Roman conquest [11]. This fruit was used in alimentation of different populations, because to obtain higher amounts of flour than the potato [12].

The legacy of the Hippocratic and Galenic medicines influenced the approach methodology in the Renaissance (this work integrates in this epoch), valued the knowledge of constitutional individual idiosyncrasies, was discussed whether it was at issue the restoration or preservation of your health. In this way, thecure began to be in general highly individualized to be observed a specific adjustment to the symptomatology of the patient in question [13]. Emerged the sensitivity to the need to individualize the treatment of the diseases, and the cures presented in Amato Lusitano already was an example of such individualized treatments.

This study is doubly important because allows contribute to increased knowledge about the History of Science about chestnut and permits to reflect on the contribute of the History of Science for Education 
in Science. In this perspective, the use of the History of Science in science teaching, is advantageous for the process of teaching and learning, provides: promoting a better understanding of scientific concepts and methodology of science; historical approaches connect the development of individual with the development of scientific ideas; the History of Science is necessary for understanding its nature and examine life and time in which they lived scientists individually, it humanizes the treatment of scientific subjects, making them less abstract and more attractive to students [14]. Thus, learning science is done in a meaningful way and that positively contributes to general education [15].

The work is structured as follows: introduction that addresses the framework of the study, the methodology applied, some considerations on the application of chestnut introducing the cure and make the discussion of the results and for last, the conclusions.

\section{Methodology}

For this work a qualitative methodology was used, applying the document analysis. The data collection was made on primary sources, because they are more reliable records and also was used some secondary sources, to be properly comprehensive [6]. The basis of this study was the work Centúrias de Curas Medicinais, translated by Firmino Crespo and published by the New University of Lisbon in 1980 (Figure 2) [3].

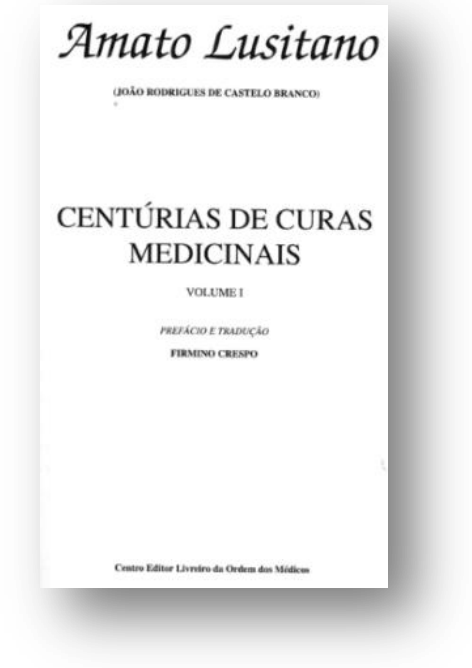

Figure2. Frontispiece of the work Centúrias de Curas Medicinais of Amato Lusitano, 1553, translated by Firmino Crespo (edited by the College of Medical Sciences, New University of Lisbon, 1980) [16].

\section{Some Questions Regarding The Therapeutic APPLication OF BROWN}

Below presents some of the cures and treatments at which the Portuguese doctor used the nuts for the therapeutic treatments. In each cure, as already mentioned, do the presentation of the patient and then the comments.

They are mention six cures: one each century, exception of the $5^{\text {th }}$ century, where was not found none cure, when it was applied the chestnut.

In XCII Cure ${ }^{1}$ which is an erosion of the stomach, head phlegm, dry cough and strong, and of other things that led the patient to the death, says the following:

"Catherine, daughter of (...) the noble João Gondulano, (...) of seventeen yearsold lived since early ages in the company of the nuns of St. Bartholomew, not with the intention of becoming a religious (...) for this occasion began suffering from gnawing around the mouth of the stomach, not so much, however, it was realized there come great loss. With the passing of years (...) not only worsened as also start to suffering from large burning around the stomach along with bites. (...) Finally, to conclude in a few words because of a bad mood deep in the stomach, his idleness and sadness, since remain that mixed up in prison because of semen retention and hot liver, was born a false aqueous humor, (...).

${ }^{1}$ I Century, XCIICure, p. 162 
So for distilling chest cavity (...) caused to dry cough and fever every day for two to three hours with cooling members (...). Once the disease began in the stomach, it has to care of this first (...). We prescribe this syrup: P.: syrup heratsease and dwarf jujubino, half an ounce; poppies, one ounce; lettuce water, three ounces andmix all the ingredients.

(...) After a short time, this girl with cough can expectorate true blood and felt increased pain in full chest. For these reason we advise her to repeat again, but this time to take the spoons. Outwardly greased up the place with Countess unguent or chestnut husks. (...).

Finally, suspended menstruation began to worsen and more behold her very severe cough (...) it seemed that the chest was opened (...). Aggravatedall the mentioned diseases and fallen forces, died on 28 July 1549.

Comments: The free-flowing that mostly died this girl was salty. This salty mood (...)is formed in two ways: one by the putrefaction of humors, another by mixing the serous moisture with the humor; because of the rottenness of moods, as with such boiling parts made more land do all salty humor. (...) It is true that the more the mood is salty, the more thick and hot. "

In this cure unguent chestnut husk was used for to calm the cough and ease the intense pain that this caused in the chest. When applied in this area, helped the patient to breathe and relax the chest muscles, thus helping to reduce the urge to cough and pain that the patient felt chest.

In LIIICure ${ }^{2}$, the title of a girl who died because of a poorly cured dysentery, concerns:

"A ten years old girl began suffering from dysentery in the large intestine. We understand this clinical case because various stools with a blood fragments, and is fixed on the lower part of the abdomen pains and cramps. As per our statement would apply it some medicine and felt some improvement but after a brief conversation her parents meant us not we go back over to visit her. I don't know was the fever of greed that led to make this decision.

(...) Next to us was another doctor see her and under its tyrannical power she died in a few days.

Comments: Since it is known a wide collection of appropriate medicines to dysenteric patients, however we remember here, some of them for the reader to have within your reach. First place purgatives; then the abstergents and scrubbers; sedatives what covering the intestines, and finally the constringent.

(...) Constringent: wild pears, lapidosa corna, loquats, toasted rice, cooked twice lentils without shells, chestnut husks, deer horn burned (...). All this is possible to prepare enemas, unguents, salves, plasters, poultices, fomentations, fumigations, bags, potions, cakes, pills and others that are filled with the practices books (...) ".

For this curing, the chestnut husk was again referenced, but in this case as a constricting which can be used to prepare a unguent of chestnut husk, helping to cure dysentery. The constringent were a type of medicines suitable for patients suffering from dysentery, because internally it allows the simultaneously treatmentof the diarrhea andthe bleeding, both caused by this disease. This type of medicine aims to close blood vessels, preventing patients bleed to the death.

In LXVI Cure ${ }^{3}$, presenting to an acre humor, down from the head to the mouth causing thrush and then dysentery, mention the following: "Constantine, a german national (...) sixty years old, had a free-flowing mood acre to the head for his mouth and startedto suffer from ulcers that the greeks called thrush. To cure these he used drugs and drinks simple pink syrup prepared with endive, consequentlythe mood acre spent the intestines and hence was born dysentery. Evacuated a lot with very strong pain below the navel (...).

\footnotetext{
${ }^{2}$ II Century, LIII Cure, p. 245

${ }^{3}$ III Century LXVI Cure p. 366
} 
(...) Our whole intent was to stop the descent of the head mood for the intestines, deriving it to the nose and other similar regions. In him stomach it was applied a dressing and under the navel an unguentof chestnuthusk, with this treatment he was in good health in seven days. "

In these provide cure the chestnut husk was used again to prepare an unguent, for the purpose of ease the severe pain that the patient felt in the area below the navel, from the successive evacuations which was due to dysentery.

XLIII Cure ${ }^{4}$ is about continuous fever accompanied distressful dysentery, refers: "A great man who lives on the street of fish guys, (...), began to be attacked by a continuous fever jointly cramps, that is dysenteric flow. He was a strong young man of sanguine temperament with thick, reddish urine. The pulse was sparse, dense and robust (...). In the lower region of abdomen used an unguentby chestnuts husk (...). The disease it lasted ten days.

Comments: When an attack occurs with fever and dysentery simultaneous, we allow a vein opening was made once or twice (...) ".

For this cure chestnut, namely his husk has been used for the preparation of asalve, which is applied on the lower abdomen area to calm the pain caused by the patient's large bowel movements suffered by thedisease.

In XI Cure ${ }^{5}$, referring to a boy who had dysentery, the author says:

"The son of Nicholas Palmota, patrician of Ragusa with three years old, was suffering dysentery, casting out of parings by intestines mixed with blood. (...). To the belly was applied unguent-ofcountess or other called chestnut husks, with these, and little else, he reached cure, not being necessary to resort to enemas with astringent properties. "

In this curethe chestnut was used for the preparation of a lotion of chestnut husks, whose purpose was to apply in the abdomenfor calm and decrease the pain that the child feel due to the evacuation of suffering and which were accompanied by parings, taking this medicine given its contribution to the healing of the patient.

Finally, the XVI ${ }^{6}$ Cure, present which refersblood vomit, Amato reports the following case:

"A young woman of twenty years old, sanguine temperament, without eye pain, head or any other organ of the body, it felt suddenly vomiting blood with little cough, from the rupture of a vein (...).

Indeed, raging in her body very bilious blood became more accurate with her drink wine made with ginger and cloves. (...) Also recommended with the seed sumac scattered instead of flavorings which is not omitted rice or lentils with the shell taken in this case, as green brown or dry smoke, and acorns (...). Drinking water source or prepared coriander ".

In this last healing, chestnut was used in food to accompany the meat, for the purpose of constraining, that is, as already noted, closing the blood vessels of the patient in order to avoid that again expels blood from the mouth.

\section{Conclusions}

Amato Lusitano used chestnuts with therapeutic application, it's possible finda significant number of healings where this doctor used this fruit, finding in practically all centuries, the reference to the chestnut unguents.

The key therapeutic utility of the chestnuts is the preparation of unguent to be applied in two situations: in the area of the abdomen to reduce the pain and in the case of dysentery caused by chest to relieve dry and hacking cough. Therefore,these fruit can be also used in the preparation of constraining forthe cure of dysentery disease.

${ }^{4}$ IV Century, XLIII Cure p. 59

${ }^{5}$ VI Century XI Cure p. 216

${ }^{6}$ VII Century XVI Cure p. 359 
This study allows too understand the nature of scientific knowledge and the essential role of chestnutsfrequently used in the European alimentation had in the cures effected by this important Renaissance doctor. The history of science is also essential in science education because in this case allows demonstrate the contribution of Amato Lusitano and his work for the increase of knowledge in Medicine area and expose the importance of chestnuts in the contribution of therapeutic medicine in the XVI century.

\section{REFERENCES}

[1] Rodrigues, I., A gravidez e o parto nas Centúrias de Amato Lusitano,Revista de Historia de la Medicina y Epistemologia Medica.1(1), 1-18 (2009).

[2] Rodrigues, I., Amato Lusitano e as perturbações sexuais - Algumas contribuições para uma nova perspetiva de análise das Centúrias de Curas Medicinais, Ph.D. Thesis Universidade de Trás-osMontes e Alto Douro.Pp.7, 97, 108(2005).

[3] Carvalho, A. M. C., and Rodrigues, I., Algumas considerações sobre a aplicação da castanha na terapêutica - o contributo de Amato Lusitano. Ata do XV Encontro Nacional de Educação em Ciências - Tendências atuais em Educação em Ciências, Portugal. (2014).

[4] Lusitano, A., Index Dioscorides, ioanne Roderi co Casteli Albi Lusitano autore. Leon: Apud Theobaldum Paganum, 1558, 183 p.

[5] Nabais, J. M., O humanismo na medicina: a importância de Amato Lusitano na visão ecuménica de Ricardo Jorge,Medicina na Beira Interior da pré-História ao Século XXI. 24, 21 - 27 (2010).

[6] Carvalho, A. M. C., and Rodrigues, I. T., Evolution of chestnut illustrations in works of XVI century - a contribution to the history of botany, International Journal of History and Cultural Studies (IJHCS). 28(2), 20 - 27 (2016).

[7] Cardoso, M. Saúde e Ambiente: Perspetivas Amatianas e Darwinianas, Medicina na Beira Interior da Pré-História ao Século XXI, 24, 28- 35 (2010).

[8] Bounous, G., and Guarda, A. In Castagno. Origine e cenni storici.Itália: Edagricole, 2002, ch. 1, pp. 3-17.

[9] Lage, J., Castanea - Uma dádiva dos Deuses, 2ª ed.Braga: Paraíso do Livro.31-32 (2006).

[10] Bounous, G., and Bounous, A. G., Among the chestnut trees in Cuneo Province. Cune: Edizioni Metafore, 1999, $10 \mathrm{p}$.

[11] Gosselet, J., Cours élémentaire de botanique... Description des familles et des espèces utiles. Anatomie et physiologie végétales, $14^{\mathrm{a}}$ ed. Paris: E. Belin. (1898).

[12] Londe, C. Nouveaux éléments d'hygiène, $2^{\mathrm{a}}$ ed. Paris: J. B. Baillière. (1838).

[13] Hall, R. A revolução na ciência 1500-1750. Lisboa: Edições 70. (1988).

[14] Matthews, M. Science Teaching. The Role of History and Philosophy of Science. Nova York: Routledge. (1994).

[15] Sequeira, M. and Leite, L., A História da ciência no ensino-aprendizagem das ciências, Revista portuguesa de educação. 1(2), 29 - 40 (1988).

[16] Lusitano, A. Centúrias de Curas Medicinais. Tradução Firmino Crespo. Lisboa: CELOM (editada pela Faculdade de Ciências Médicas da Universidade Nova de Lisboa, 1980) (1553).

\section{AUTHORS' BIOGRAPHY}

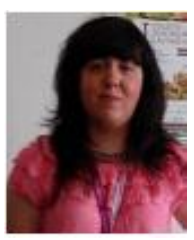

Andreia MarliseCarneiro de Carvalho, Degree in Biology and Geology, master's degree in Biology and Geology teaching in the $3^{\text {rd }}$ cycle of basic education and secondary education. PhD student in Earth Sciences and Life, the perform research on the theme of chestnut.

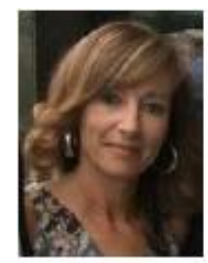

Isilda Teixeira Rodrigues, Assistant Professor attheUniversityof Trás-os-Montes and Alto Douro, Portugal. PhD in Education/History of Science. Published 27 articles in journals, 80 proceedings and 10 books and chapters. Works in Science Education, Health Education, History of Science and Didactics of Science. 